\title{
EDITORIAL
}

\section{Antipathy against SDD is justified: We are not sure}

\author{
Michael Quintel, Francesco Vasques and Luciano Gattinoni*
}

๑ 2018 Springer-Verlag GmbH Germany, part of Springer Nature and ESICM

"Our doubts are traitors, and make us lose the good we oft might win by fearing to attempt".

(William Shakespeare)

Critical illness disequilibrates homeostasis, decreases immune defense, disturbs protective barrier functions of the human body, and leads to microbial colonization patterns different from those in states of health.

The gastrointestinal tract is exposed to multiple forces that affect its microbiome and immunity. Consequently, the intestine becomes a reservoir of "unusual" microorganisms that might either induce general infection via translocation or, via regurgitation and aspiration, lead to pneumonia, with consecutive sepsis. These pathogenetic mechanisms generated the hypothesis that decontaminating the digestive tract might reduce the risks for nosocomial infections. Selective oral decontamination (SOD) and selective digestive decontamination (SDD) were introduced in the early 1980s [1]. SOD aims at influencing the colonization of the oropharynx with a combination of topically applied non-absorbable antibiotics, while SDD combines SOD with a short course of intravenous antibiotics (mostly cephalosporins, alternatively a quinolone) or enteral antibiotics with the goal of systemically reducing the amount of potentially pathogenic microorganisms [2]. Since its introduction, this approach has been raising controversies and a passionate debate about the development of resistance.

The hypothesis that SDD may reduce infections and improve outcome of intensive care patients has been tested in numerous randomized controlled trials (RCTs) [3-8]. In brief, all these studies showed beneficial effects, even if they failed to reduce mortality; however, an increase in bacterial resistance was not observed, yet reporting a decrease of resistance in gram-negative bacteria without concomitant increase in the amount of gram-positive infections [9]. Some centers using SDD for more than 30 years carefully monitored their resistance patterns and have not observed the development of resistance with SDD use (J. Briegel, LMU München, 2018, personal communication). After more than 30 years, the argument that SDD will sooner or later increase microbial resistance and promote the development of multiresistant strains might not have become meaningless but has definitively lost its vigor.

In face of numerous positive RCTs, we may wonder why SDD is only rarely implemented in clinical practice [10].

Plausibility and practicability are prerequisites for the adoption of an approach into clinical practice. SDD is, with regard to plausibility, above suspicion; it generates a manageable increase in work, especially once it is established. What else might influence the adoption? Is

*Correspondence: gattinoniluciano@gmail.com

Department of Anesthesiology, Emergency and Intensive Care Medicine, University of Göttingen, Robert-Koch-Straße, 40, 37075 Göttingen, Germany

For contrasting viewpoints, please go to https://doi.org/10.1007/s0013

4-018-5144-6 and https://doi.org/10.1007/s00134-018-5183-z.

\section{实 Springer}


it the journal in which the RCT's results are published, the visibility and publicity of the authors, or simply the attractiveness of the investigated concept? Tight glucose control and low tidal volume ventilation represent targets of RCTs that were rapidly introduced into clinical practice after one positive RCT. What makes the difference? The effects of the interventions required for the aforementioned two studies are measurable and visualizable; in contrast, the effects of SDD occur with delay and they are difficult to measure or visualize. The lack of an acutely visible effect of the intervention might, beside others, be one of the reasons to be reluctant.

In addition, in the recent years, multiple bundles, interventions, and guidelines to reduce hospital-acquired infections have been introduced into clinical practice. Although the effectiveness of these interventions has not been as rigorously investigated as SDD, they might have left the impression that the potential for a further improvement in the reduction of nosocomial infections has become small, maybe too small, for justifying the efforts and risks of an intervention like SDD.

Data from historical studies where SDD was randomly applied in the same ICU might suggest a higher than usual rate of infections in control patients [11]. Consequently, the introduction of SDD into an ICU would represent an "all or none" decision that might increase reluctance. Recent publications report an impact of SDD on the gut resistome leading to the colonization with multiresistant strains [12]. The relevance of these findings remains unclear; however, they should not be neglected.

Actually, two large RCTs regarding SOD/SDD are on their way and may help to answer open questions. The RGNOSIS trial (ClinicalTrials.gov identifier NCT02208154) is being conducted in 15 ICUs in nine European countries with a cluster crossover design with 6-month periods of SOD, SDD, and oral chlorhexidine application. The primary endpoint of this study is the incidence of bacteremia with multiresistant gramnegative bacteria, while its second endpoint is mortality. The second study, the SuDDICU trial (ClinicalTrials. gov identifier NCT02389036), plans to recruit 25,000 patients in 100 ICUs in Canada, the UK, Australia, and New Zealand. In a non-crossover design, patients will be randomized-for a period of 1 year-to either SDD or standard care. The endpoints of this study are hospital mortality, antibiotic resistance and cost-effectiveness [13].

These two studies will either add more evidence in favor of SDD or further support the doubts about the vast harmlessness of this approach. However, will any result in favor of SOD/SDD change its acceptance and implementation? For the reasons given, we are not sure.

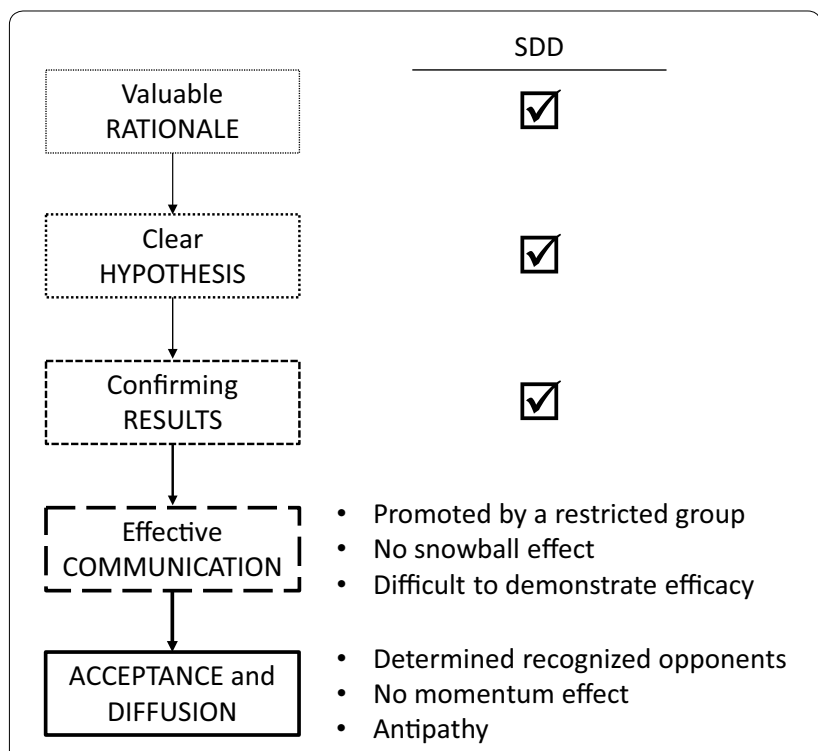

Fig. 1 Flowchart illustrates the main determinants of the acceptability of research innovations into clinical practice

The resistance against SDD is based largely on strategic, structural, and emotional considerations, rarely on scientific reasoning. The authors of this statement never applied SDD in their own institution or practice. They felt obviously never sure enough to take the effort to promote it, although the prerequisites for a reasonable intervention based on clinical trials were given (Fig. 1).

So why are they unsure? First, although the risk of development of resistance has to be rated minimal, the occurrence of multiresistant strains in the gut and the associated changes in the resistome of patients have to be carefully followed up. Second, the increasing knowledge about side effects of antibiotics on the human microbiota and human mitochondria may-apart from resistancelead to a different risk/benefit weighting, especially for prophylactic antibiotic use in a collective of patients where, because of the complexity of the underlying disease process, the probability for larger benefits is quite low $[14,15]$.

However, assuming that the studies ahead would deliver positive results still demonstrating no serious side effects of SOD/SDD, we should be fair enough to give this approach the chance "to win the good and, to be sure at the end."

Compliance with ethical standards

Conflicts of interest

The authors declare that they have no competing interests. 
Received: 18 April 2018 Accepted: 25 April 2018

Published online: 7 June 2018

\section{References}

1. Stoutenbeek CP, van Saene HK, Miranda DR, Zandstra DF (1984) The effect of selective decontamination of the digestive tract on colonisation and infection rate in multiple trauma patients. Intensive Care Med 10:185-192

2. Silvestri L, van Saene HK (2012) Selective decontamination of the digestive tract: an update of the evidence. HSR Proc Intensive Care Cardiovasc Anesth 4:21-29

3. de Smet AM, Kluytmans JA, Cooper BS, Mascini EM, Benus RF, van der Werf TS, van der Hoeven JG, Pickkers P, Bogaers-Hofman D, van der Meer NJ, Bernards AT, Kuijper EJ, Joore JC, Leverstein-van Hall MA, Bindels AJ, Jansz AR, Wesselink RM, de Jongh BM, Dennesen PJ, van Asselt GJ, te Velde LF, Frenay $\mathrm{IH}$, Kaasjager K, Bosch FH, van Iterson M, Thijsen SF, Kluge GH, Pauw W, de Vries JW, Kaan JA, Arends JP, Aarts LP, Sturm PD, Harinck HI, Voss A, Uijtendaal EV, Blok HE, Thieme Groen ES, Pouw ME, Kalkman CJ, Bonten MJ (2009) Decontamination of the digestive tract and oropharynx in ICU patients. N Engl J Med 360:20-31

4. de Smet AM, Kluytmans JA, Blok HE, Mascini EM, Benus RF, Bernards AT, Kuijper EJ, Leverstein-van Hall MA, Jansz AR, de Jongh BM, van Asselt GJ Frenay IH, Thijsen SF, Conijn SN, Kaan JA, Arends JP, Sturm PD, Bootsma MC, Bonten MJ (2011) Selective digestive tract decontamination and selective oropharyngeal decontamination and antibiotic resistance in patients in intensive-care units: an open-label, clustered group-randomised, crossover study. Lancet Infect Dis 11:372-380

5. Oostdijk EAN, Kesecioglu J, Schultz MJ, Visser CE, de Jonge E, van Essen EHR, Bernards AT, Purmer I, Brimicombe R, Bergmans D, van Tiel F, Bosch FH, Mascini E, van Griethuysen A, Bindels A, Jansz A, van Steveninck FAL, van der Zwet WC, Fijen JW, Thijsen S, de Jong R, Oudbier J, Raben A, van der Vorm E, Koeman M, Rothbarth P, Rijkeboer A, Gruteke P, Hart-Sweet $H$, Peerbooms P, Winsser LJ, van Elsacker-Niele AW, Demmendaal K, Brandenburg A, de Smet AMGA, Bonten MJM (2014) Effects of decontamination of the oropharynx and intestinal tract on antibiotic resistance in ICUs: a randomized clinical trial. JAMA 312:1429-1437

6. Oostdijk EAN, Kesecioglu J, Schultz MJ, Visser CE, de Jonge E, van Essen EHR, Bernards AT, Purmer I, Brimicombe R, Bergmans D, van Tiel F, Bosch $\mathrm{FH}$, Mascini E, van Griethuysen A, Bindels A, Jansz A, van Steveninck FAL, van der Zwet WC, Fijen JW, Thijsen S, de Jong R, Oudbier J, Raben A, van der Vorm E, Koeman M, Rothbarth P, Rijkeboer A, Gruteke P, Hart H, Peerbooms P, Winsser LJ, van Elsacker-Niele AW, Demmendaal K, Brandenburg A, de Smet AMGA, Bonten MJM (2017) Notice of retraction and replacement: Oostdijk et al. effects of decontamination of the oropharynx and intestinal tract on antibiotic resistance in ICUs: a randomized clinical trial. JAMA 317:1583-1584

7. D'Amico R, Pifferi S, Torri V, Brazzi L, Parmelli E, Liberati A (2009) Antibiotic prophylaxis to reduce respiratory tract infections and mortality in adults receiving Intensive care. Cochrane Database Syst Rev (4):CD000022

8. Price R, MacLennan G, Glen J, SuDDICU Collaboration (2014) Selective digestive or oropharyngeal decontamination and topical oropharyngeal chlorhexidine for prevention of death in general intensive care: systematic review and network meta-analysis. BMJ 348:92197

9. Daneman N, Sarwar S, Fowler RA, Cuthbertson BH, SuDDICU Canadian Study Group (2013) Effect of selective decontamination on antimicrobial resistance in intensive care units: a systematic review and meta-analysis. Lancet Infect Dis 13:328-341

10. Canter RR, Harvey SE, Harrison DA, Campbell MK, Rowan KM, Cuthbertson $\mathrm{BH}$, Selective Decontamination of the Digestive tract in critically ill patients treated in Intensive Care Unit (SuDDICU) Investigators (2014) Observational study of current use of selective decontamination of the digestive tract in UK critical care units. Br J Anaesth 113:610-617

11. Hurley JC (2014) Topical antibiotics as a major contextual hazard toward bacteremia within selective digestive decontamination studies: a metaanalysis. BMC Infect Dis 14:714

12. Buelow E, Bello González TDJ, Fuentes S, de Steenhuijsen Piters WAA, Lahti L, Bayjanov JR, Majoor EAM, Braat JC, van Mourik MSM, Oostdijk EAN, Willems RJL, Bonten MJM, van Passel MWJ, Smidt H, van Schaik W (2017) Comparative gut microbiota and resistome profiling of intensive care patients receiving selective digestive tract decontamination and healthy subjects. Microbiome 5:88

13. Price RJ, Cuthbertson BH, SuDDICU collaboration (2016) Selective decontamination of the digestive tract and oropharynx: after 30 years of debate is the definitive answer in sight? Curr Opin Crit Care 22:161-166

14. Keeney KM, Yurist-Doutsch S, Arrieta MC, Finlay BB (2014) Effects of antibiotics on human microbiota and subsequent disease. Annu Rev Microbiol 68:217-235

15. Singh R, Sripada $L$, Singh R (2014) Side effects of antibiotics during bacterial infection: mitochondria, the main target in host cell. Mitochondrion 16:50-54 